\title{
SEM of seed coat surface characters and the taxonomic relationships in the genus Sesbania Scop. (Leguminosae - Papilionoideae).
}

\author{
Mohammed H. Loutfy ; \\ Maged M. Abou-El-Enain \\ Biological Science and Geology Department, \\ Faculty of Education, Ain Shams University, \\ Roxy (Heliopolis), P.C.11341, Cairo, Egypt.
}

And

\author{
Mohammed A. El-Kholy \\ Botany Department, Faculty of Science, \\ El-Azhar University (Boys), \\ Madenit Nasr, P.C. 11371, Cairo, Egypt.
}

\begin{abstract}
Loutfy M.H.; Abou-El-Enain M.M. \& El-Kholy M.A. 1999. SEM of seed coat surface characters and the taxonomic relationships in the genus Sesbania Scop. (Leguminosae Papilionoideae). Taeckholmia 19(1): 53-61.

Criteria obtained by SEM of seed coat surface have been used to re-assess the taxonomic relationships between 19 species belonging to three subgenera of the genus Sesbania. The produced characters were analyzed by the NTSYS-pc. program package using the UPGMA clustering method. The produced phenogram supported the treatment of the three taxa Agati, Daubentonia and Sesbania as subgenera in the genus Sesbania. SEM criteria have revealed that, the genus represent a natural monphyletic group and the subgenus Sesbania is the center of the genus from which the other subgenera could have been evolved.

Key words: Leguminosae - Papilionoidae - Sesbania - Seed scan.
\end{abstract}

\section{Introduction}

Species of the genus Sesbania have a considerable economic importance in agriculture as manure for food crops; a source of wood, paper and gum; animal fodder and to maintain soil productivity as well as to improve soil structure for wheat and rice cultivation (Evans \& Rotor 1987, Arunin et al., 1988; Ladha et al., 1989; Shioya \& Ito, 1990). Sesbania belongs to tribe Robinieae of the subfamily Papilionoideae and comprises about 50, mostly annual species distributed throughout tropical subtropical regions (Mabberley, 1997).

Taxonomic structure of Sesbania has always been different between taxonomists. Adanson (1763), Bailey (1949) and Mabberley (1987) had considered Agati, Daubebtonia, Glottidium and Sesbania as distinct genera closely related to each other. However, Bentham (1859) had treated the former three taxa as sections within the genus Sesbania. Siwundla \& Stucky $(1986 ; 1989)$ confirmed the treatment of Glottidium as a monotypic genus and retained Daubentonia as a section of Sesbania. On the other hand, Baker (1876), Gillette (1963), Burbidge (1965), Sachet (1988) and Monterio (1994) considered Agati, Daubentonia and Sesbania as the main subgenera of Sesbania. Difficulties in determining the specific relationships have been encountered by the 
workers in the genus because of the insufficient information as well as the conflicting nomenclature of the species (Saraswati et al. 1993; Badr et al. 1998).

The species relationships within the genus have been delimited based on their vegetative, floral and seed shape characters (Monteiro, 1994); cytological observations (Salimuddin, 1993; Forni-Martins et al. 1994; Abou- El-Enain et al., 1998) and SDSPAGE of seed protein profiles (Saraswati et al. 1993; Badr et al. 1998). However, scanning electron microscopy (SEM) of seed coat criteria have not been applied at the subgeneric level in Sesbania.

SEM of seed coat surface is a useful technique in the identification and classification of various taxa (Barthlott, 1981). A comparison of surface scan patterns of the seed coat has efficiently been used in studying species of some genera including Vigna (Kumar et al., 1984), Cassia (Ponomarino et al., 1990; Bhattacharya \& Saha, 1991), Sesbania (Seth \&Vijaya-raghavan, 1991) and Vicia (Chernoff et al., 1992).

In the present work, the SEM of seed coat surface criteria are used to reassess the taxonomic relationships of 19 species in the genus Sesbania in the light of morphological, cytological and SDS-PAGE of seed protein characters.

\section{Materials and Methods}

Seeds of the species studied were provided by the gene bank of International Livestock Center for Africa (ILCA), Ethiopia, the plant genetic resources conservation unit of the United States Department of Agriculture (USDA), Gorgia, USA and the Botanical Garden of the Faculty of Education, Ain Shams University (BGFE), Egypt. The source and origin of the examined materials are given in table 1. Plant of almost all taxa have been grown in open ground in the Botanical Garden of the Faculty of Education, Ain Shams University, where voucher specimens are kept at the Department of Biological Sciences and Geology.

For the study of the seed coat surface, seeds were mounted with colloidal silver on copper stubs, coated with a thin layer of gold in Polaron E 5000, the epidermal seed coat were photographed by a Jeol-T- Scanning Microscope at the magnification of 750 . Terminology of Stearn (1966); Stant (1973) and Barthlott (1981) has been used to describe the characteristics of the seed coat. For the data analysis, total number of the recorded characters in each taxon were scored and coded as shown in Table 1 for creating the data matrix of computation. The relationships between the studied taxa; have been expressed by average taxonomic distance (dissimilarity); and demonstrated as phenogram based on the analysis of the recorded characters using the NTSYS program package for IBM-pc as described by Rohlf (1993). In the computer analysis, the taxa are numbered as indicated in Table (1). 
Seed coat surface characters in Sesbania

Received 28 January 1999. Revision accepted 30 April 1999.

$-55-$ 


\section{Results and Discussion}

Investigation of the SEM patterns of seed coat surface in the species of the three subgenera i.e. Agati, Daubentonia and Sesbania (Fig. 1 and Table 1) has revealed the presence of a considerable number of common characters. These include the polygonal reticulate spermoderm cells; wavy shape, medium thickness and the presence of the striation of anticlinal walls as well as the rough highly striated periclinal walls. The speromoderm cells in species of the subgenus Agati were characterized by the polygonal shape, monomorphic pattern, the cell size about $16 \times 11 \mu \mathrm{m}$ and the highly striated periclinal walls, while the speromoderm cells in species of subgenus Daubentonia were characterized by hexagonal, monomorphic and cell size about $12 \times 10 \mu \mathrm{m}$.

The phenogram illustrating the relationships between the studied species based on the character analysis using UPGMA clustering (Fig. 2) has revealed that, the species studied are divided into three major groups belonging to the three subgenera Daubentonia, Agati and Sesbania that were distinguished from each other at the distance levels of 0.6, $0.9 \& 1.45$, respectively, and clustered together at the 1.62 level. The first group (i.e. Daubentonia) included $S$. virgata (19) and S. speciosa (17). The second group (i.e. Agati) included S. grandiflora (6), S. tetraptera (18) \& S. formosa (4) from which the former species (6) was separated, while the latter two species (i.e. $18 \& 4$ ) were clustered together. The third group (i.e. Sesbania) comprised three subgroups, one included S. goetzeii (5), S. rostrata (14), S. hitistyla (8), S. greenwayii (7) and S. pachycarpa (12) from which $S$. bispinosa (1) and $S$. cericea (15) were separated. The second subgroup included $S$. exaltata (2), S. macrantha (10) and S. quadrata (13). Two species namely $S$. microphylla (11) and $S$. exasperata (3) were distinct from other species in the latter subgroups. The third subgroup included S. leptocarpa (9) and S. sesban (16).

Badr et al. (1998) recorded considerable differences between the sections Agati and Daubentonia and treated them as heterogeneous groups distinguished both from each other as well as from species of the subgenus Sesbania. They also pointed out that, the seed protein data was insufficient for their delimitation in two separate genera as proposed by Adanson (1763) Bailey (1949) and Mabberley (1987). However, the present data confirm the retention of the three taxa Agati, Daubentonia and Sesbania in the genus Sesbania and their delimitation as three subgenera as proposed by Baker $(1871 ; 1876)$, Gillette (1963), Burbidge (1965), Sachet (1988), Monteiro (1994) and Badr et al.(1998).

In the light of the cytological data (Salimuddin, 1993; Forni-Martins et al. 1994 and Abou El-Enain et al.1998) and SDS-PAGE of seed protein data (Saraswati et al. 1993; Badr et al. 1998), the subgenus Sesbania was considered as the center of the genus from which the subgenera Agati and Daubentonia were derived. The SEM of seed coat features supports this conclusion. Three closely related SEM seed coat surface patterns (Fig. 1 and Table 1) have been observed in species of the subgenus Sesbania and recorded in species of both subgenera Agati \& Daubentonia at the same time. The first pattern is the polygonal polymorphic with a hairy like appendages and recorded in nine species namely S. exasperata (3), S. goetzii (5), S. greenwayi (7), S. hirtistyla (8), S. microphylla (11), S. pachycarpa (12), S. quadrata (13), S. rostratra (14) and S. sericea (15). The second is the reticulate slightly hexagonal pattern and is recorded in $S$. bispinosa (1), $S$. leptocarpa (9) and S. sesban (16). The latter two patterns are observed in species of the subgenera Agati \& Daubentonia, respectively and can be considered as transition forms between the three subgenera revealing the common origin between them. The third is the ill-defined pattern and is recorded in two species i.e. S. exaltata (2) and S. macrantha (10). 
Furthermore, these data indicate that, the genus Sesbania represents a natural monophyletic group in the tribe Robinieae. The latter view has previously been concluded by Badr et al. (1998) based on the similarities in SDS-PAGE pattern; vegetative and floral characters (Montiero, 1994), the uniformity in the basic chromosome number (Goldblatt, 1981) and homogeneity in karyotype symmetry (Salimuddin, 1993; Vijayakumar \& Kuriachan, 1995 and Abou-El-Enain et al.1998). 
Seed coat surface characters in Sesbania

Received 28 January 1999. Revision accepted 30 April 1999.

$-58-$ 


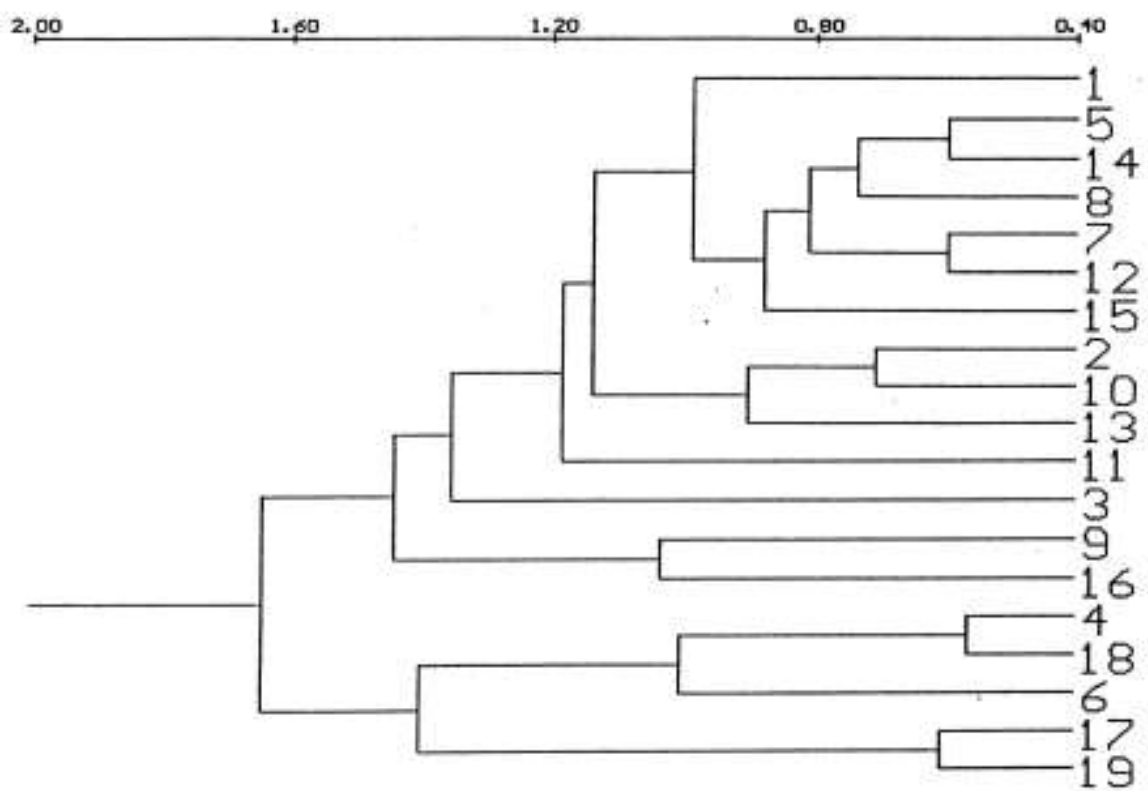

Fig. 2: The phenogram illustrating the relationships between the species studied; numbered as in Table 1; using the UPGMA clustering method.

\section{Acknowledgement}

The authors wish to express their deepest gratitude to Prof. Dr. Abdel Fattah Badr, proffessor of plant genetics \&head of Botany Department, Faculty of Science, Tanta University for his useful criticism and offering help in the computer analysis.

\section{References}

Abou-El-Enain, M.; El-Shazly, H. \& El-Kholy, M., 1998: Karyological studies in some African species of the genus Sesbania. Cytologia 63: 1- 8.

Adanson, M. 1763: Fam. Pl. vol. 2, pp. 326-513.

Arunin, S.; Dissatopan, C.; Anuluxtipan, Y. \& Nana, D., 1988: Potential of Sesbania as a green manure in saline soils in Thailand. In: Green manure in rice farming. Proceeding of a symposium on sustainable agriculture, Int. Rice Res. Inst., Philippines, pp. 83-95.

Badr, A.; Abou-El-Enain, M. M. and El-Shazly, H. H., 1998: Variation in seed protein electrophoretic pattern and species relationships in Sesbania. Proceedings of the $6^{\text {th }}$ Egyptian Botanical conference, Cairo University (24-26 November, 1998). Pp. 493-501.

Bailey, L. H., 1949: Manual of cultivated plants. Macmillan company, New York.

Baker, J. G., 1876: Flora of British India, vol.2, and p.115. 
Barthlott, W., 1981: Epidermal and seed surface characters of plants: Systematic applicability and some evolutionary aspects. Nord. J. Bot. 1: 345-355.

Bentham, G., 1859: Papilionaceae. In Martius, C. P. (ed.), Flora Brasiliensis vol. 15, part 1 , Munich, Germany.

Bhattacharya, A \& Saha, P.K., 1991: Ultrastructure of seed coat and water uptake pattern of seed during germination in Cassia sp. Seed Sc. \& Tech., 18: 197-103.

Burbidge, N. T., 1965: The Australian species of Sesbania Scop. Aust. J. Bot. 13:103-141.

Chernoff, M.; Plitmann, U. \& Kislev, M.E., 1992: Seed characters and testa texture in species of the Vicieae, their taxonomic significance. Isr. J. Bot., 41: 167-186.

Evan, D.O.\& Rotor, P.P., 1987: Sesbania in Agriculture, Boulder Co., USA, Westview Press.

Forni-Martins, E. R., Franchi-Tanibata, M. \& Cardelli-de-laucens, M., 1994: Karyotypes of seven species of Sesbania Scop. . Cytologia 59: 479-482.

Gillette, J.B., 1963: Sesbania in Africa (excluding Madagascar) and Southern Arabia. Kew Bull. 17:19-159.

Goldblatt, P., 1981: Cytology and phylogeny of Leguminosae. In Polhill, R. M. \& Raven, P. H., (Eds.): Advances in legume systematics, Part 2, pp. 427- 463. Royal Bot. Gard. , Kew.

Kumar, D.; Rangaswamy, N.S.\& Dinesh, K., 1984: SEM studies on seed surface of wild and cultivated species of Vigna Savi. Proc. Ind. Acad. Pl. Sc., 93: 35-42.

Ladha, J. K., Miyan, S. \& Garcia, M., 1989: Sesbania rostrata as green manure for lowland rice. Growth, N2 fixation of Azorhizobium species. Inoculation and effects on succeeding crop yield and nitrogen balance. Biol. Fert. Soils 7:191-197.

Mabberley, D. J., 1987: The plant book: A portable dictionary of the higher plants. Cambridge University Press New York.

Mabberley, D. J., 1997: The plant book: A portable dictionary of the Vascular plants. Cambridge University Press.

Monteiro, R., 1994: The species of Sesbania Scop. in Brazil. Arq. Biol. Tecnol. 37: 309331.

Ponomareno, S.F.; Khrzhanovskii, Ya, V. \& Buivids, K.R., 1990: Seed structure of species in the genus Cassia (Tourn) L. Adaptat-sionnaya izmenchivost rastenii pri introduktsii, 40:162-164.

Rohlf, F. J., 1993: NTSYS-pc, Numerical taxonomy and multivariate analysis system. Exeter Software, New York.

Sachet, M. H., 1987: The littoral species of Sesbania in the South Pacific islands and its relatives. Bull. Mus. Nat. Hist., Paris, Adansonia 9: 3-28.

Salimuddin, R. B., 1993: Karyological studies in the genus Sesbania. Cytologia 58: 241126.

Saraswati, R., Matoh, T, Sasai, T. Phupaibul, P., Lumpkin, T., Kobayashi, M. \& Sekiya, J., 1993: Identification of Sesbania species from electrophoretic patterns of seed proteins. Trop. Agric. 70: 282-285.

Seth, N. and Vijayaraghavan, M.R., 1991: Differentiation of the seed coat in Sesbania speciosa. Proc. Ind. Acad. Pl. Sc., 100: 301-310.

Shioya, T. \& Ito, J., 1990: Growth trait of tropical legume Sesbania spp. Jpn. J. Farm. Work Res. 25: 33-34.

Siwundla, N. \& Stucky, J., 1986: Systematic anatomy of leaves, cotyledons and pericarps in Sesbania of the Southeastern United States. Amer. J. Bot. 73: 786-787. 
Siwundla, N. \& Stucky, J., 1989: Perciarp anatomy in Sesbania of the Southeastern USA and its systematic significance. Castanea 54:164-171.

Stant, M. T., 1973: The role of the scanning electron microscope in plant. Kew Bull., 28: 105-115.

Stearn, W. T., 1966: Botanical latin . Nelson \& Sons. London .P. 506 ,507.

Vijayakumar, M. G., Kuriachan, P. I., 1995: Karyomorphology of five taxa of Sesbania from south India. Cytologia 48:329-234. 
Table 1: Source, origin and subgeneric delimitation of the species studied and codes of the produced spermoderm characters for the numerical analysis.

\begin{tabular}{|c|c|c|c|c|c|c|c|c|c|c|c|c|c|c|}
\hline \multirow{3}{*}{ No } & \multirow{3}{*}{ Species } & \multirow{3}{*}{ Source } & \multirow{3}{*}{ Origin } & \multirow{3}{*}{ Subgenus } & \multicolumn{10}{|c|}{ Spermoderm cell characters } \\
\hline & & & & & \multirow[t]{2}{*}{ Shape } & \multirow[t]{2}{*}{$\begin{array}{c}\text { Pattern } \\
\text { Pans }\end{array}$} & \multirow[t]{2}{*}{ Size } & \multicolumn{4}{|c|}{$\begin{array}{r}\text { Anticlinal walls } \\
\end{array}$} & \multicolumn{3}{|c|}{ Periclinal walls } \\
\hline & & & & & & & & Shape & Thick & Ster. & Level & Shape & Text. & Ster. \\
\hline 01 & S. bispinosa (Jacq.) Wright & USDA & India & Sesbania & 1 & 1 & 1 & 1 & 2 & 2 & 1 & 1 & 4 & 2 \\
\hline 02 & S. exaltata Cory & USDA & Australia & Sesbania & 2 & 1 & 0 & 0 & 2 & 1 & 1 & 1 & 1 & 1 \\
\hline 03 & S. exasperata H.B.K. & USDA & Argentina & Sesbania & 2 & 1 & 0 & 0 & 2 & 0 & 2 & 1 & 0 & 0 \\
\hline 04 & S. formosa (F. Muell) Burb. & USDA & Australia & Agati & 1 & 0 & 3 & 1 & 2 & 2 & 1 & 0 & 1 & 2 \\
\hline 05 & S. goetzii Harms & ILCA & Tanzania & Sesbania & 2 & 1 & 1 & 1 & 2 & 1 & 1 & 1 & 0 & 1 \\
\hline 06 & S. grandiflora (L.) Pior. & ILCA & Ethiopia & Agati & 1 & 0 & 3 & 0 & 2 & 1 & 1 & 1 & 3 & 2 \\
\hline 07 & S. greenwayii Gill. & ILCA & Tanzania & Sesbania & 2 & 1 & 1 & 1 & 1 & 2 & 1 & 1 & 0 & 1 \\
\hline 08 & S. hirtistyla Gill. & ILCA & Tanzania & Sesbania & 2 & 1 & 1 & 1 & 2 & 1 & 2 & 1 & 2 & 1 \\
\hline 09 & S. leptocarpa Cronq. & USDA & Afghanistan & Sesbania & 1 & 1 & 0 & 1 & 2 & 2 & 0 & 1 & 4 & 1 \\
\hline 10 & S. macrantha Phill. \& Hutch. & ILCA & Tanzania & Sesbania & 2 & 1 & 0 & 0 & 2 & 1 & 1 & 0 & 1 & 0 \\
\hline 11 & S. microphylla Phill.\&Hutch. & ILCA & Tanzania & Sesbania & 2 & 1 & 0 & 1 & 0 & 1 & 1 & 1 & 0 & 0 \\
\hline 12 & S. pachycarpa DC. & ILCA & Senegal & Sesbania & 2 & 1 & 1 & 1 & 2 & 2 & 1 & 1 & 2 & 1 \\
\hline 13 & S. quadrata Gill. & ILCA & Tanzania & Sesbania & 2 & 1 & 0 & 0 & 1 & 1 & 0 & 1 & 0 & 1 \\
\hline 14 & S. rostrata Brem. \& Obem. & ILCA & Tanzania & Sesbania & 3 & 1 & 1 & 1 & 2 & 1 & 1 & 1 & 2 & 1 \\
\hline 15 & S. sericea (Willd.) Link. & BGFE & Egypt & Sesbania & 2 & 1 & 1 & 1 & 2 & 1 & 1 & 1 & 2 & 1 \\
\hline 16 & S. sesban (L.) Merr. & BGFE & Egypt & Sesbania & 1 & 1 & 1 & 0 & 2 & 2 & 1 & 1 & 4 & 2 \\
\hline 17 & S. speciosa Taub. & USDA & Ethiopia & Daubentonia & 0 & 0 & 2 & 0 & 0 & 1 & 1 & 0 & 0 & 1 \\
\hline 18 & S. tetraptera & USDA & Swaziland & Agati & 1 & 0 & 3 & 1 & 2 & 1 & 1 & 0 & 1 & 2 \\
\hline 19 & S. virgata (Cav.) Pers. & USDA & Uruguay & Daubentonia & 0 & 0 & 2 & 0 & 0 & 1 & 0 & 0 & 0 & 1 \\
\hline
\end{tabular}

USDA= United States Department of Agriculture; ILCA= International Livestock Center for Africa gene bank ; BGFE = Botanical Garden of the Faculty of

Education; Thick. $=$ Thickness, Ster. $=$ Striation, Text. $=$ Texture. Character codes: Cell shape: hexagonal = 0, polygonal = 1, irregular $=2$, illdefined $=3$;

Cell pattern: monomorphic $=0$, polymorphic $=1$; Cell size: $\approx 5 \times 3 \mu \mathrm{m}=0, \approx 7 \times 4 \mu \mathrm{m}=1, \approx 12 \times 10 \mu \mathrm{m}=2, \approx 16 \times 11 \mu \mathrm{m}=3$. Anticlinal walls, Shape:

straight $=0$, wavy $=1$; Thickness: thin $=0$, medium $=1$, thick $=2 ;$ Steriation: absent $=0$, few $=1$, many $=2 ;$ Level $:$ normal $=0$, raised $=1$, highly raised $=2$.

Periclinal walls, Shape: flat $=0$, concave $=1$ : Texture: smooth $=0$, rough $=1$, hairy $=2$, tuberculate $=3$, illdefined $=4$. Striation: absent $=0$, few $=1$, numerous $=2$.

Received 28 January 1999. Revision accepted 30 April 1999. 
Seed coat surface characters in Sesbania 